\title{
ANALISIS KEMAMPUAN MAHASISWA TERHADAP PENGGUNAAN ALAT LABORATORIUM FISIKA
}

\author{
Zainuddin $^{1}$, Salam ${ }^{1}$, Muh. Yusuf Hidayat ${ }^{2}$ \\ ${ }^{1}$ Fakultas Tarbiyah dan Ilmu Keguruan, IAIN Kendari \\ ${ }^{2}$ Fakultas Tarbiyah dan Keguruan, UIN Alauddin Makassar \\ Email: zainuddin.fisika11@gmail.com
}

\begin{abstract}
Abstrak
Penelitian ini bertujuan untuk mengetahui tingkat kemampuan mahasiswa Program Studi Tadris Fisika IAIN Kendari dalam menggunakan alat-alat serta faktor-faktor yang mempengaruhi tingkat kemampuan mahasiswa dalam menggunakan alat-alat laboratorium. Penelitian ini merupakan penelitian deskriptif kuantitatif dengan pendekatan metode gabungan. Subjek dari penelitian ini yaitu mahasiswa program studi Tadris Fisika angkatan 2017 yang ditentukan dengan teknik purposive random sampling. Instrumen yang digunakan adalah lembar kuesioner dan Tes Perbuatan (Performance test). Teknik analisis data yang digunakan menggunakan metode campuran melalui uji t-test pada taraf signifikansi 5\%. Hasil penelitian menunjukkan bahwa pengetahuan awal mahasiswa berpengaruh secara signifikan terhadap kemampuan dalam mengoperasikan peralatan laboratorium. Hasil penelitian juga menunjukkan bahwa kondisi dan keterbatasan alat dan bahan laboratorium berpengaruh secara signifikan terhadap kemampuan mahasiswa dalam mengoperasikan alat laboratorium.
\end{abstract}

Kata Kunci: Kemampuan; laboratorium fisika; peralatan laboratorium

\begin{abstract}
This research aims to investigate the ability level of students majoring in physics in operating laboratory instruments at an state Islamic institute in South East Sulawesi and the factors affecting student's ability in operating the laboratory tools. This quantitative study used mixed-method approach. The participants of the research are students of Physics study program determined by purposive random sampling techniques.The instruments used are questionnaire sheet and a test (Performance test). The data is then analyzed using a mixed method through the t-test at 5\% significance level. The results of this research indicate that some factors can influence the students' ability in operating laboratory equipment namely (1) the initial knowledge of laboratory equipment. Based on the results of the study, the regression
\end{abstract}


coefficient value is 0.004 of significance smaller than the value of the level of significance of 0.05. It can be concluded that the students' ability in operating laboratory instrument is significantly good, (2) the availability of laboratory tools and materials based on the research results show that the value of their significance of 0.047 is smaller than the value of the level of significance of 0.05. This indicates that the conditions and limitations of the tools and materials of the laboratory significantly affect the students' ability in operating laboratory equipment.

Keywords: Ability; laboratory instruments; physics laboratory

\section{A. PENDAhULUAN}

Perkembangan ilmu pengetahuan khususnya ilmu fisika lahir, tumbuh dan berkembang dari rasa ingin tahu manusia tentang fenomena dan gejala yang terjadi di alam semesta. Titik tolak dari rasa keingintahuan itu memunculkan keinginan-keinginan untuk menyelidiki gejala alam tersebut sehingga dalam penyelidikannya dibutuhkan suatu gambaran yang dapat memberikan jawaban terhadap masalah yang dihadapi.

Pembelajaran fisika tidak semata-mata hanya fokus pada kajian pengetahuan konsep dan fakta, tetapi pembelajaran fisika merupakan suatu proses penemuan. Proses ini yang diimplikasikan dalam pengajaran fisika, sesuai dengan tuntutan kurikulum 2013 dimana pengajaran fisika dilakukan dengan menggunakan pendekatan ilmiah yang menuntut keaktifan peserta didik. Pendekatan ilmiah dapat dilakukan melalui kegiatan praktikum (kegiatan laboratorium) yang menuntut peserta didik mahir dalam menggunakan peralatan laboratorium. Melalui kegiatan praktikum, peserta didik melakukan olah pikir dan juga olah tangan.

Salah satu tuntutan ilmu yang memerlukan kegiatan dan proses belajar melalui praktikum adalah mata pelajaran fisika. Sopiatin (2010) menyatakan bahwa laboratorium fisika merupakan sarana pendidikan yang digunakan sebagai tempat berlatih, sehingga siswa dapat mengadakan kontak dengan objek yang dipelajari secara langsung melalui pengamatan maupun dengan percobaan. Selain itu, Decaprio (2013) mengungkapkan bahwa laboratorium fisika merupakan wadah untuk memperkuat pemahaman tentang konsep fisika, baik bagi peserta didik (praktikan di laboratorium) maupun bagi guru fisika itu sendiri. Dari beberapa pendapat tentang laboratorium dapat diketahui bahwa laboratorium fisika merupakan sarana pendidikan yang digunakan untuk melaksanakan praktikum fisika sehingga peserta didik dapat berlatih secara langsung dengan objek yang dipelajari sehingga siswa memperoleh pemahaman yang optimal berkaitan dengan materi fisika yang dipelajari. Mata pelajaran fisika tidak cukup jika disampaikan secara teori saja, melainkan 
harus dilaksanakan praktikum di laboratorium yang memiliki sarana dan prasarana yang mendukung.

Melakukan percobaan atau eksperimen dalam sains membutuhkan alat dan bahan. Kelancaran keberhasilan suatu percobaan terkadang pada penggunaan alat yang baik dan tepat. Untuk dapat memiliki keterampilan menggunakan alat-alat praktikum, dengan sendirinya peserta didik harus menggunakan dengan benar alat-alat praktikum tersebut agar memperoleh pengalaman langsung. Selain itu, peserta didik harus mengetahui mengapa atau bagaimana menggunakan alat itu (NSTA, 2008).

Pentingnya peranan penggunaan alat-alat laboratorium terhadap pembelajaran fisika sehingga diharapkan siswa mampu menganalis hasil-hasil pengamatan dari percobaan yang dilakukan. Akan tetapi, hal ini dapat terwujud dan terlaksana jika guru sebagai fasilitator dan moderator dalam proses pembelajaran memiliki kemampuan dan keterampilan dalam mengoperasikan alat-alat laboratorium. Dengan demikian peserta didik akan memperoleh pengetahuan dalam bentuk konsep, prinsip, hukum serta teori tentang fisika.

Awitaningsih (2012) menyatakan pemanfaatan fasilitas laboratorium fisika di sekolah dapat mendukung pelaksanaan pembelajaran fisika di sekolah. Selanjutnya, Sundari (2008) menyatakan siswa sangat antusias jika pembelajaran dilakukan dengan lebih variatif seperti dengan kegiatan praktikum.

Kegiatan praktikum merupakan percobaan yang ditampilkan guru dalam bentuk demonstrasi yang berlangsung di laboratorium atau tempat lain (Emha. 2002). Guru fisika dituntut tidak hanya menguasai dan mengajarkan konsep fisika saja, tetapi diluar dari konteks itu guru juga dituntut untuk mampu mengoperasikan peralatan laboratorium dalam merancang suatu percobaan, sehingga menciptakan proses belajar mengajar yang tepat sasaran. Namun kenyataannya, di lapangan masih banyak kendala dan kesulitan yang dialami oleh guru-guru bidang studi fisika dalam mengoperasikan alat-alat laboratorium. Walapun pemerintah telah mengadakan dan mendistribusikan peralatan laboratorium, namun masih ada sekolah yang belum memanfaatkan dan mengelola laboratorium secara baik. Hal itu mungkin disebabkan kurangnya kemampuan dan keterampilan guru dalam menggunakan peralatan laboratorium tersebut.

Efektivitas pengelolaan dan manajemen laboratorium dipengaruhi oleh banyak faktor, diantaranya adalah kemampuan guru dalam mengelola laboratorium sebagai tempat praktikum dan pengelolaan pembelajaran berbasis praktikum. Kemampuan tersebut meliputi kemampuan menggunakan dan mengelola alat dan bahan laboratorium yang sangat diperlukan dalam mendukung proses keberhasilan pembelajaran fisika (Dyasayu, 2011). Pengelolaan laboratorium Fisika meliputi koordinasi kegiatan praktikum, penyusunan jadwal kegiatan laboratorium, pemantauan pelaksanaan dan 
mengevaluasi kegiatan laboratorium. Pentingnya penggunaan laboratorium bisa membantu mempersiapkan peserta didik untuk siap beradaptasi menyelesaikan berbagai macam permasalahan yang terdapat dalam ilmu pengetahuan (Myers \& Dyer, 2005).

Institut Agama Islam Negeri Kendari merupakan satu-satunya Institut Agama Islam di Sulawesi Tenggara memiliki visi menjadi pusat pengembangan kajian Islam transdisipliner di kawasan Asia tahun 2045. Visi ini mulai dicetuskan sejak tahun 2015 saat terjadinya transformasi kelembagaan dari STAIN menjadi IAIN. Hal ini menjadi tantangan tersendiri bagi fakultas-fakultas dalam lingkup IAIN, khususnya Fakultas Tarbiyah dan Ilmu Keguruan (FATIK) yang memiliki program studi berbasis sains dalam meramu suatu sistem pengajaran yang dapat memudahkan tercapainya visi tersebut. Seiring dengan transformasi itu, FATIK IAIN Kendari telah membuka program studi Tadris Fisika yang akan menciptakan dan mencetak calon-calon guru fisika. Dalam proses perkuliahan, calon-calon guru fisika dituntut harus memiliki kompetensi keagamaan, kompetensi pedagogik dan kompetensi profesional (kompetensi kepakaran bidang ilmu). Dalam penerapannya, kompetensi profesional disampaikan baik melalui teori maupun praktik. Praktikum yang dilakukan meliputi praktikum Fisika Dasar dan Elektronika Dasar. Namun demikian kemampuan mahasiswa sebagai calon guru fisika dalam praktikum masih relatif rendah. Masalah ini terlihat ketika pelaksanaan praktikum masih banyak mahasiswa belum mampu mengoperasikan peralatan laboratorium secara baik dan benar. Hal inilah yang mendorong penulis untuk melakukan penelitian tentang analisis kemampuan mahasiswa dalam menggunakan alat laboratorium fisika.

\section{B. METODE PENELITIAN}

Penelitian ini menggunakan metode penelitian deskriptif kuantitatif dengan pendekatan metode gabungan (mixed methods) (Sugiyono, 2013). Subjek dari penelitian ini yaitu mahasiswa program studi tadris fisika angkatan 2017 berjumlah 25 orang masing-masing terdiri dari 7 mahasiswa dan 18 mahasiswi yang ditentukan secara purporsive sampling. Data yang digunakan dalam penelitian ini berupa data primer yang merupakan data utama yang diambil langsung dari para informan yang dalam hal ini adalah para praktikan, asisten laboratorium, dan dosen pengampuh mata kuliah. Sedangkan data sekunder merupakan data yang tidak langsung diambil dari para informan, akan tetapi melalui dokumen, yaitu dokumen berupa buku penuntun, KIT alat Laboratorium dan berbagai sumber lainnya yang dapat mendukung penelitian ini dalam menggumpulkan informasi.

Pengumpulan data dalam penelitian ini menggunakan seperangkat instrumen pengumpulan data yang terdiri atas dua instrument, yaitu: lembar kuesioner, dan tes perbuatan (performance test) merupakan tes yang diberikan 
kepada mahasiswa berupa tes untuk mengukur kemampuan dalam mengoperasikan peralatan laboratorium pada mahasiswa program studi Tadris Fisika meliputi ketepatan penggunaan alat, kemampuan mahasiswa merangkai alat, dan keselamatan kerja. Setelah data telah terkumpul kemudian dianalisis dengan menggunakan metode campuran sebagaimana teori metode campuran yang dijelaskan oleh Creswell yaitu analisis secara kuantitatif melalui uji-t berpasangan (paired t-test) dan analisis secara deskriptif kuantitatif dan kualitatif (Creswell, 2010).

\section{HASIL PENELITIAN DAN PEMBAHASAN \\ a. Deskripsi Tingkat Kemampuan Mahasiswa dalam Mengoperasikan Peralatan Laboratorium}

Berdasarkan hasil data melalui instrument tes dan memperoleh data sebagaimana yang diinterpretasikan pada masing-masing indikator (diadaptasi dari Said, 2011) maka hasilnya dipaparkan pada bagian ini.

\section{Kemampuan mempersiapkan alat dan bahan yang digunakan dalam percobaan}

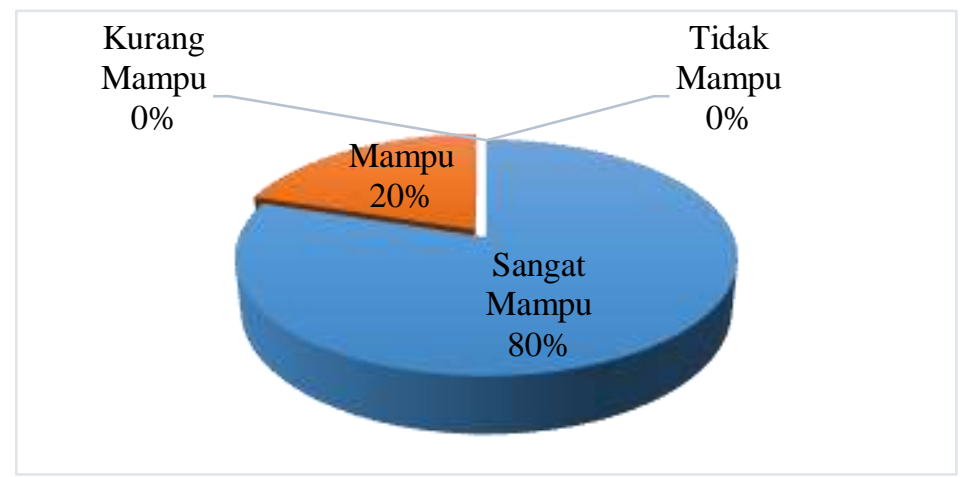

Gambar 1. Kemampuan mempersiapkan alat dan bahan

Kemampuan mempersiapkan alat dan bahan yang digunakan dalam percobaan terlihat dari dua aspek yaitu mengambil dengan hati-hati dan secara teliti alat dan bahan sesuai petunjuk buku penuntun, dan mangkalibrasi alat dan bahan (diadaptasi dari Said, 2011). Diagram di atas menunjukkan bahwa 80\% mahasiswa tadris fisika IAIN Kendari berada pada kategori sangat mampu, 20\% mahasiswa berada pada kategori mampu, sedangkan pada indikator ini tidak ditemukan mahasiswa pada kategori kurang mampu dan tidak mampu dalam mempersiapkan alat dan bahan yang digunakan dalam eksperimen. Tingginya nilai persentase ini menunjukkan bahwa dalam kegiatan menyiapkan alat dan bahan mahasiswa dinyatakan sudah kompeten. Disamping itu, mahasiswa pada dasarnya memiliki latar belakang dari jurusan 
IPA sewaktu dibangku sekolah sehingga dalam hal penyiapan alat dan bahan mudah untuk dilakukan.

\section{Kemampuan mengecek kelengkapan alat dan bahan}

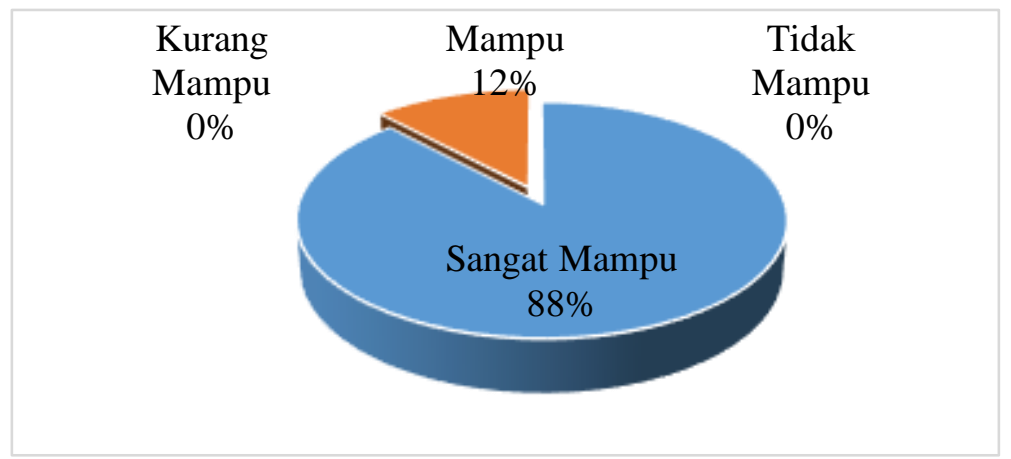

Gambar 2. Kemampuan mengecek alat dan bahan

Berdasarkan diagram di atas, kemampuan mahasiswa dalam mengecek kelengkapan alat dan bahan sebelum praktikum menunjukkan bahwa $88 \%$ berada pada kategori sangat mampu, $12 \%$ mahasiswa dapat melakukan dengan kategori mampu. Oleh karena itu, secara keseluruhan mahasiswa sangat mampu untuk melakukan pengecekan kelengkapan alat dan bahan. Menurut Said (2011), keterampilan mengecek kelengkapan alat dan bahan terdiri atas beberapa aspek, di antaranya mengambil alat dan bahan, memastikan kondisi alat dan bahan dalam keadaan baik, serta mengkalibrasi alat dan bahan secara empiris.

\section{Kemampuan merangkai alat sesuai dengan prosedur percobaan}

Dalam indikator ini ada beberapa aspek yang diukur, yaitu merangkai alat sesuai prosedur kerja, menghubungkan serta mengkoneksikan antara alat yang satu dengan yang lainnya, serta menyusun alat dan bahan secara sistematis (Said, 2011).

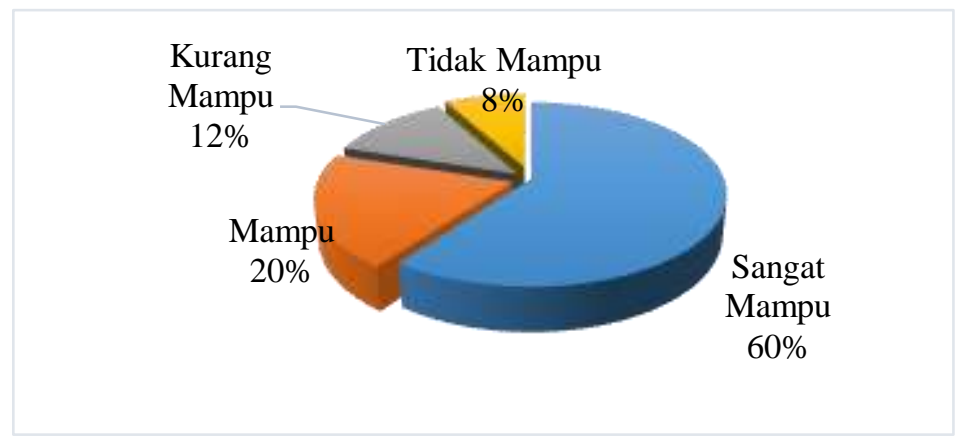

Gambar 3. Kemampuan merangkai alat 
Diagram di atas menunjukkan bahwa $60 \%$ mahasiswa tadris fisika IAIN Kendari dalam kompetensi ini berada pada kategori sangat mampu, 20\% mahasiswa berada pada kategori mampu, $12 \%$ berada pada kategori kurang mampu, dan $8 \%$ berada pada kategori tidak mampu. Dalam indikator ini, dari 3 aspek yang diukur, ada aspek yang terlihat kurang dan tidak mampu dilakukan mahasiswa, yaitu aspek menghubungkan serta mengkoneksikan antara alat yang satu dengan yang lainnya. Kenyataan di lapangan menunjukkan bahwa kadang mahasiswa sudah menyusun rangkaian secara benar, akan tetapi dalam memasang kabel pada alat ukur masih terbalik.

\section{Kemampuan dalam mengoperasikan alat ukur Ammeter dan Voltmeter dengan tepat}

Dalam indikator ini ada beberapa aspek yang diukur yaitu menentukan Nilai Skala Terkecil (NST alat), menentukan skala atas dan skala bawah alat ukur, dan menentukan batas ukur (Said, 2011).

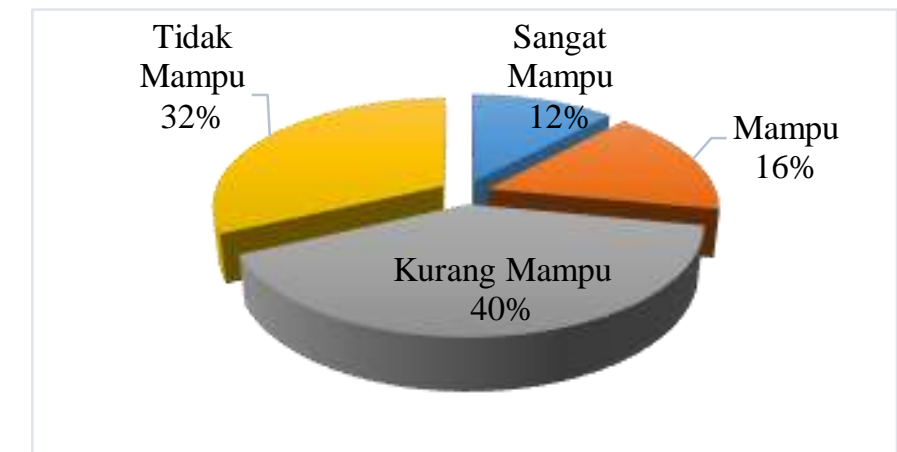

Gambar 4. Kemampuan mengoperasikan alat ukur Ammeter

Berdasarkan hasil penelitian yang ditunjukkan diagram di atas, $12 \%$ mahasiswa tadris fisika IAIN Kendari sangat mampu dalam kompetensi ini. Sebanyak 16\% mahasiswa berada pada kategori mampu, $40 \%$ berada pada kategori kurang mampu, dan 32\% berada pada kategori tidak mampu. Dalam hal ini, yang menjadi kendala bagi mahasiswa ialah mereka kurang mampu dalam menentukan nilai skala terkecil. Hal ini karena mereka masih mengalami kesulitan dalam sinkronisasi skala atas dan bawah dengan batas ukur pas alat ukur ammeter dan voltmeter. Hasil ini relevan dengan penelitian yang dilakukan oleh Safriana (2017) yang menunjukkan bahwa terdapat pengaruh yang positif dan signifikan antara kemampuan penggunaan alat ukur listrik terhadap kemampuan psikomotrik mahasiswa pada praktikum elektronika dasar yang ditunjukkan melalui kontribusi performa penggunaan alat ukur listrik terhadap kemampuan psikomotrik mahasiswa pada praktikum elektronika dasar sebesar 30,1\%. 


\section{Kemampuan mengoperasikan alat ukur Stopwatch dengan tepat}

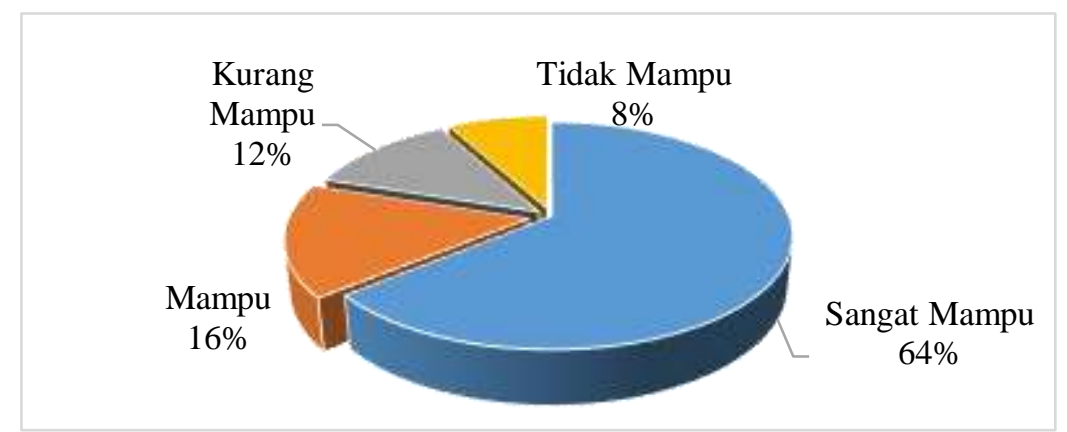

Gambar 5. Kemampuan mengoperasikan alat ukur Stopwatch

Dalam indikator ini, ada beberapa aspek yang diukur yaitu menentukan Nilai Skala Terkecil (NST alat) dan cara menggunakan stopwatch (Said, 2011). Diagram diatas menunjukkan bahwa 64\% mahasiswa tadris fisika IAIN Kendari berada pada kategori sangat mampu untuk kompetensi ini. Sebanyak $16 \%$ mahasiswa berada pada kategori mampu, 12\% berada pada kategori kurang mampu, dan $8 \%$ berada pada kategori tidak mampu. Dalam indikator ini, pada umumnya mahasiswa sudah berada dalam kondisi pencapaian sangat mampu. Akan tetapi, yang masih menjadi kendala adalah mereka kurang mampu dalam menentukan nilai skala terkecil. Hal ini disebabkan skala pada stopwatch terlalu kecil dan sangat berentetan antara skala yang satu dengan lain sehingga mereka sulit terbaca oleh merka guna penentuan hasil pengukuran.

\section{Kemampuan mengoperasikan alat ukur mikrometer sekrup}

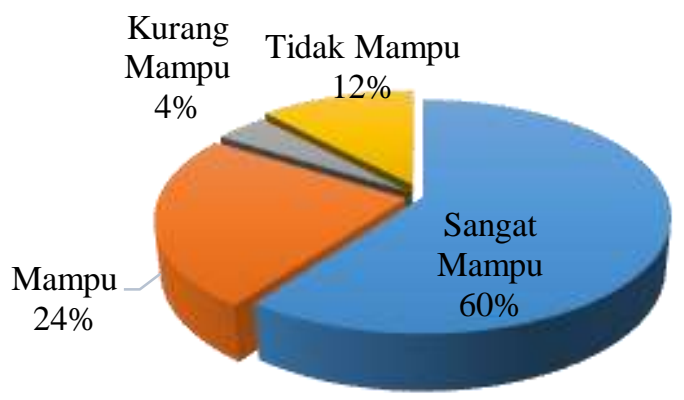

\section{Gambar 6. Kemampuan mengoperasikan alat ukur mikrometer sekrup}

Terkait kompetensi mengoperasikan alat ukur mikrometer sekrup, diagram di atas menunjukkan bahwa $60 \%$ mahasiswa tadris fisika IAIN Kendari berada pada kategori sangat mampu, $24 \%$ berada pada kategori mampu, $4 \%$ berada pada kategori kurang mampu, dan $12 \%$ berada pada 
kategori tidak mampu. Dalam indikator ini, ada beberapa aspek yang diukur, yaitu menentukan Nilai Skala Terkecil (NST Alat), memutar skala geser, dan mengunci klop pada mikrometer sekrup (Said, 2011). Dalam hal ini, pada umumnya mahasiswa sudah berada dalam kondisi pencapaian sangat mampu. Akan tetapi, yang menjadi kendala adalah mereka kurang mampu dalam menentukan nilai skala terkecil. Hal ini disebabkan mereka pada umumnya tidak mampu mengkombinasikan nilai skala terkecil pada skala utama dan skala geser. Disamping itu, kurangnya pengetahuan tentang alat membuat beberapa mahasiswa gemetar atau grogi saat memegang alat ukur tersebut.

\section{Kemampuan mengoperasikan alat ukur dengan tepat dan sesuai waktu yang ditentukan}

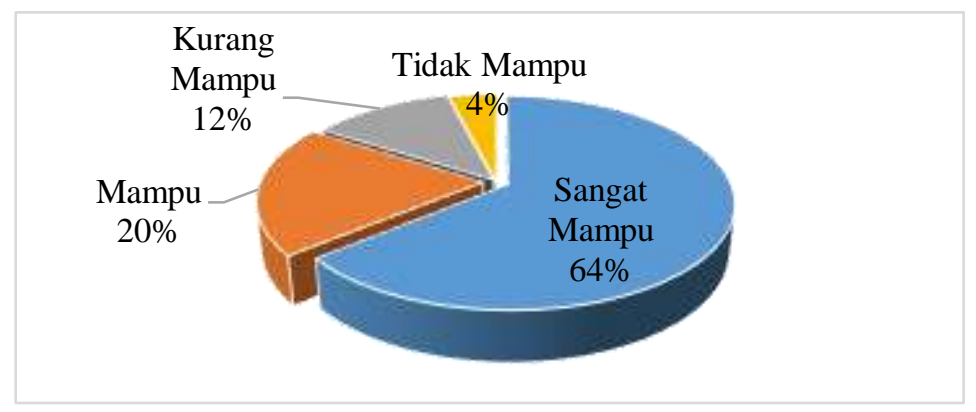

Gambar 7. Kemampuan mengoperasikan alat ukur sesuai waktu

Berdasarkan diagram di atas, hasil penelitian menunjukkan sebanyak 64\% mahasiswa tadris fisika IAIN Kendari dalam kompetensi ini berada pada kategori sangat mampu, 20\% mahasiswa berada pada kategori mampu, 12\% berada pada kategori kurang mampu, dan $4 \%$ berada pada kategori tidak mampu dalam mengoperasikan alat ukur dengan tepat dan sesuai waktu yang ditentukan. Dalam indikator ini, ada beberapa aspek yang diukur, yaitu merakit alat dalam waktu lima menit dan merakit alat dengan benar dalam waktu tiga menit (Said, 2011). Terkait kompetensi ini, pada umumnya mahasiswa sudah berada dalam kondisi pencapaian mampu. Akan tetapi, yang menjadi kendala bagi mahasiswa adalah mereka kurang mampu dalam menentukan nilai skala terkecil. Hal ini disebabkan mahasiswa pada umumnya tidak mampu mengkombinasikan nilai skala terkecil pada skala utama dan skala geser. Disamping itu, kurangnya pengetahuan tentang alat tersebut sehingga ada beberapa mahasiswa yang masih grogi saat memegang alat ukur.

\section{Kemampuan memasang alat ukur secara tepat berdasarkan rangkaian}

Pada indikator ini ada beberapa aspek yang diukur yaitu memasang alat ukur dengan tepat dan benar, serta menempatkan alat ukur pada pada posisinya yang benar (Said, 2011). 


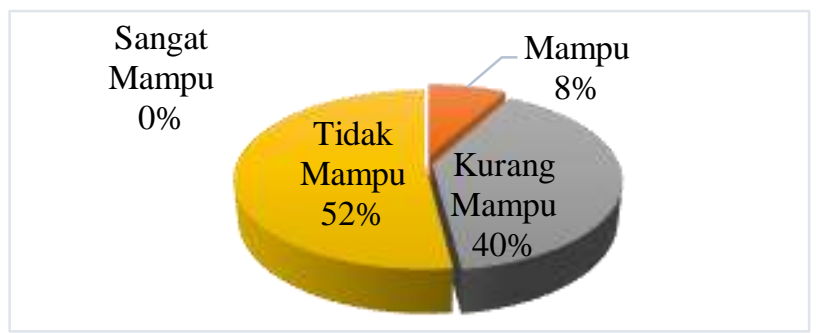

Gambar 8. Kemampuan mengoperasikan alat ukur sesuai rangkaian

Berdasarkan diagram diatas hasil penelitian menunjukkan bahwa tidak ada mahasiswa tadris fisika IAIN Kendari dalam kompetensi ini berada pada kategori sangat mampu dengan kata lain mahasiswa tidak memiliki kemampuan dalam indikator ini, $8 \%$ mahasiswa berada pada kategori mampu, $40 \%$ berada pada kategori kurang mampu, dan $52 \%$ berada pada kategori tidak mampu pada kemampuan memasang alat ukur secara tepat berdasarkan rangkaian. Hal ini disebabkan rumitnya rangkaian dari percobaan seri-paralel sehingga mahasiswa bingung untuk menempatkan alat sesuai fungsi dan urutan rangkaiannya. Disamping itu, mahasiswa masih bingung dan terbalik dalam memasang kabel pada masing-masing alat ukur.

\section{Kemampuan ketelitian dalam mengamati alat ukur}

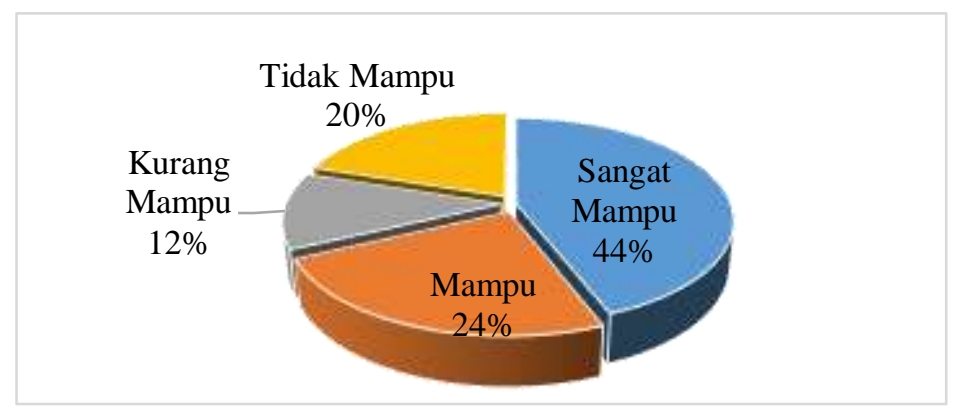

Gambar 9. Kemampuan ketelitian

Pada indikator ini, ada beberapa aspek yang diukur yaitu mengamati kesalahan titik nol (KTN) alat ukur dan mengamati kesalahan kalibrasi alat. Berdasarkan diagram diatas hasil penelitian menunjukkan bahwa $44 \%$ mahasiswa tadris fisika IAIN Kendari dalam kompetensi ini berada pada kategori sangat mampu dengan kata lain mahasiswa pada dasarnya punya kemampuan ketelitian dalam mengamati alat ukur. Hal ini ditandai dengan mahasiswa mampu untuk menentukan kesalahan titik nol alat ukur dan mengkalibrasi alat secara tepat, $24 \%$ mahasiswa berada pada kategori mampu, $12 \%$ berada pada kategori kurang mampu, dan $20 \%$ berada pada kategori tidak 
mampu. Rendahnya kemampuan mahasiswa pada indikator disebabkan karena sebagian mahasiswa belum mampu mengkalibrasi alat secara tepat khususnya alat ukur voltmeter dan ammeter. Disamping itu, sebagian alat yang digunakan ada yang rusak (abnormal) sehingga dalam mengkalibrasi mahasiswa bingung dalam menentukan NTS alat ukur itu.

\section{Kemampuan membaca hasil pengukuran pada alat ukur}

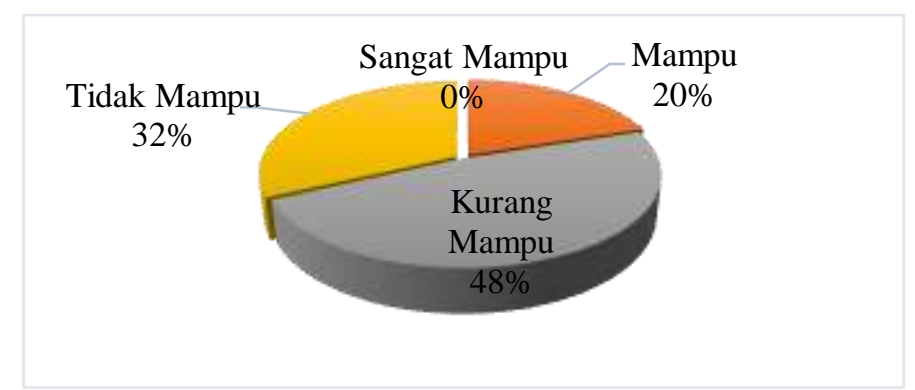

Gambar 10. Kemampuan membaca hasil pengukuran pada alat

Hasil penelitian ini menunjukkan bahwa tidak satupun mahasiswa tadris fisika IAIN Kendari yang berhasil dalam indikator ini yang menunjukkan perolehan 0\% berada pada kategori sangat mampu, 20\% mahasiswa berada pada kategori mampu, $48 \%$ berada pada kategori kurang mampu, dan $32 \%$ berada pada kategori tidak mampu. Dalam indikator ini, ada beberapa aspek yang diukur yaitu perekaman data sesuai besaran dan satuan alat ukur dan membaca data dengan menyesuaikan dengan angka penting (Said, 2011). Rendahnya kemampuan mahasiswa pada indikator ini disebabkan ketidakmampuan mereka membaca perekaman data secara jelas, khususnya pada alat ukur multimeter (voltmeter digital). Disamping itu, kemampuan mahasiswa dalam menuliskan angka penting masih sangat kurang. Seharusnya, angka penting dituliskan dua angka di belakang koma, tetapi mahasiswa menuliskan apa yang terbaca pada alat ukur tanpa memperhatikan angka penting.

\section{Kemampuan menginterpretasikan hasil pengamatan berisi data sesuai dengan percobaan}

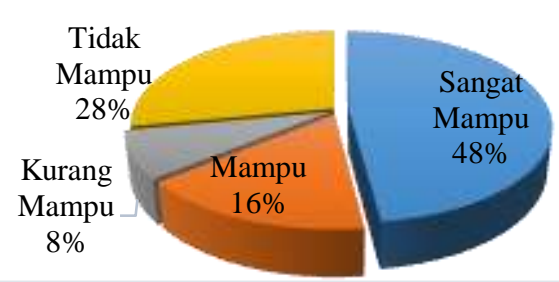

Gambar 11. Kemampuan mengiterpretasikan hasil pengamatan 
Berdasarkan diagram di atas, hasil penelitian ini menunjukkan bahwa mahasiswa tadris fisika IAIN Kendari dalam indikator ini memperoleh $48 \%$ berada pada kategori sangat mampu, $16 \%$ mahasiswa berada pada kategori mampu, $8 \%$ berada pada kategori kurang mampu, dan $28 \%$ berada pada kategori tidak mampu. Ada beberapa aspek yang diukur dalam indikator ini, yaitu menuliskan hasil pengukuran dan diinterpretasikan dalam besaran dan satuannya, dan menuliskan hasil pengukuran sesuai data yang ditunjukkan pada alat ukur. Indikator ini menunjukkan bahwa sebagian mahasiswa dinyatakan sangat mampu dalam menuliskan hasil pengukuran dan menginterpretasikan dalam besaran dan satuan. Akan tetapi, sebagian mahasiswa ditemukan mampu menuliskan besarannya tapi tidak dapat menginterpretasikan sesuai dengan data yang diperoleh.

\section{Kemampuan mengambil kesimpulan yang secara baik dan benar sesuai dengan hasil pengamatan}

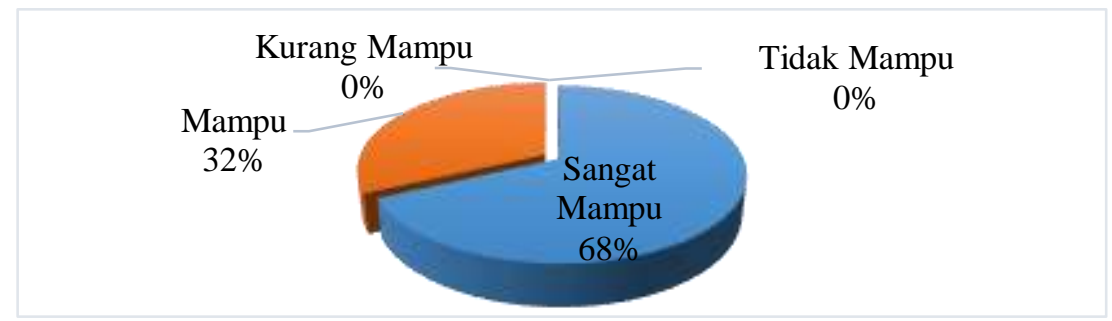

Gambar 12. Kemampuan mengambil kesimpulan

Diagram di atas menunjukkan bahwa mahasiswa tadris fisika IAIN Kendari dalam indikator ini memperoleh $68 \%$ berada pada kategori sangat mampu, 32\% mahasiswa berada pada kategori mampu, $0 \%$ berada pada kategori kurang mampu, dan 0\% berada pada kategori tidak mampu. Dalam indikator ini ada beberapa aspek yang diukur yaitu menyimpulkan hasil pengukuran dan membandingkan antara kesimpulan hasil pengukuran dengan teori (Said, 2011). Pada indikator ini menunjukkan bahwa hampir seluruh mahasiswa dinyatakan sangat mampu dalam menuliskan kesimpulan dan membandingkan dengan teorinya.

\section{Kemampuan menghubungkan antara variabel yang satu dengan yang lain}

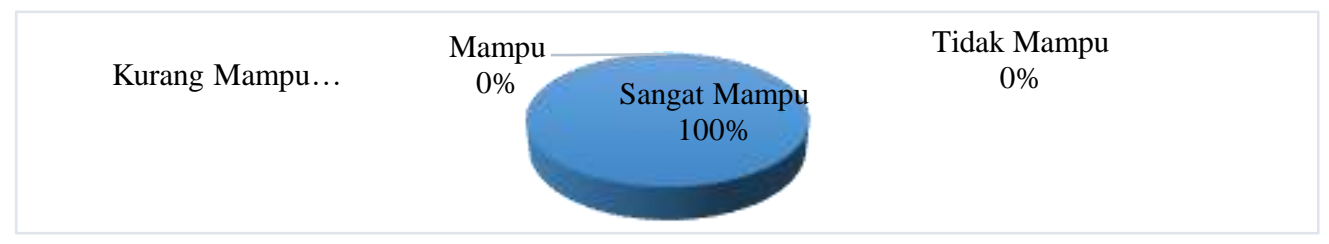

Gambar 13. Kemampuan menghubungkan antar variabel 
Berdasarkan hasil penelitian pada indikator kemampuan menghubungkan antara variabel yang satu dengan yang lain menunjukkan bahwa seluruh mahasiswa tadris fisika IAIN Kendari dalam indikator ini memperoleh $100 \%$ dikategori sangat mampu dalam menghubungkan antara variabel yang satu dengan yang lain, $0 \%$ mahasiswa berada pada kategori mampu, $0 \%$ berada pada kategori kurang mampu, dan $0 \%$ berada pada kategori tidak mampu. Dalam indikator ini ada beberapa aspek yang diukur yaitu menentukan besaran variabel yang diukur dan variabel yang diukur jelas dan dapat disajikan. Pada indikator ini, mahasiswa menunjukkan kemampuan mereka dalam menghubungkan antara variabel secara jelas.

\section{Kemampuan Merapikan dan Kebersihan Setelah Praktikum}

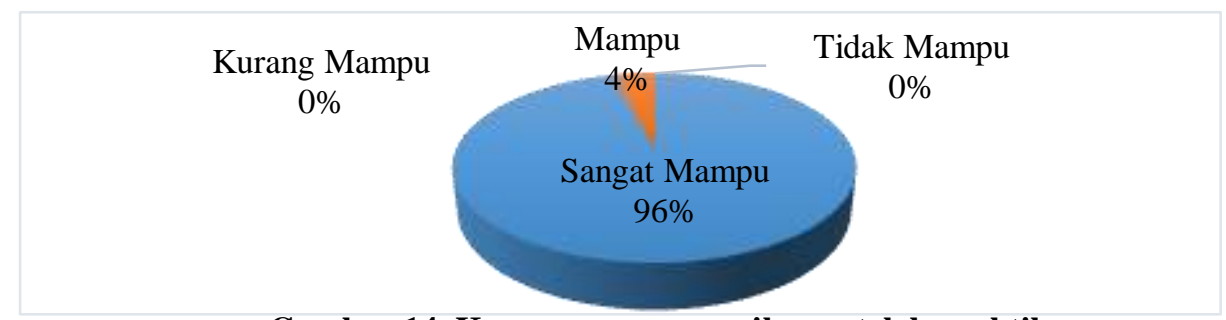

Gambar 14. Kemampuan merapikan setelah praktikum

Berdasarkan hasil penelitian pada indikator ini menunjukkan bahwa mahasiswa tadris fisika IAIN Kendari dalam indikator ini memperoleh 96\% berada pada kategori sangat mampu, 4\% mahasiswa berada pada kategori mampu, $0 \%$ berada pada kategori kurang mampu, dan $0 \%$ berada pada kategori tidak mampu. Dalam indikator ini ada beberapa aspek yang diukur yaitu membersihkan alat dan bahan setelah digunakan, dan merapikan serta menyimpang alat dan bahan pada tempatnya. Pada indikator ini menunjukkan bahwa secara keseluruhan mahasiswa sudah berada pada kategori sangat mampu.

\section{Kemampuan membuat kesimpulan yang dibuat lengkap dengan grafik}

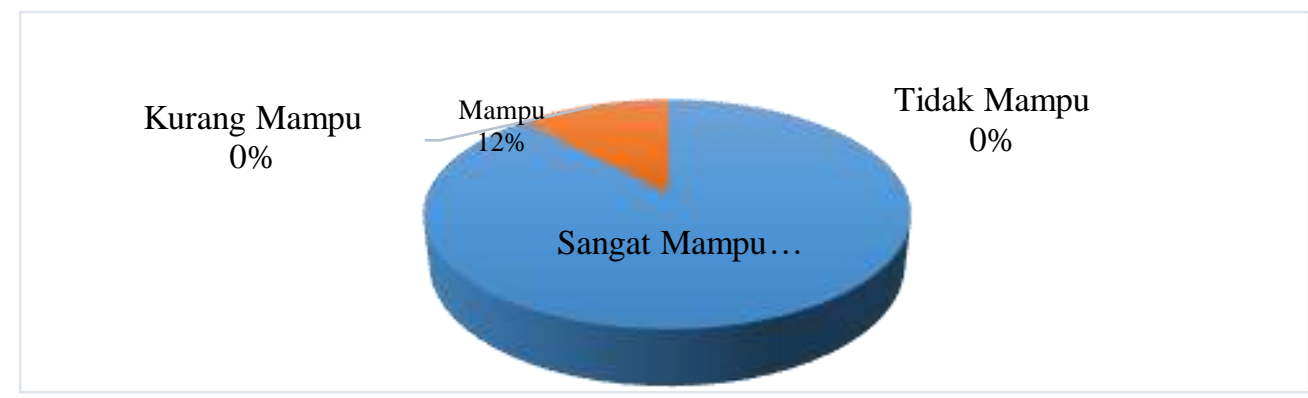

Gambar 15. Kemampuan membuat kesimpulan menggunakan grafik 
Berdasarkan hasil penelitian pada indikator ini, diagram di atas menunjukkan bahwa mahasiswa tadris fisika IAIN Kendari dalam indikator ini memperoleh $88 \%$ berada pada kategori sangat mampu, $12 \%$ mahasiswa berada pada kategori mampu, $0 \%$ berada pada kategori kurang mampu, dan $0 \%$ berada pada kategori tidak mampu. Dalam hal ini, ada beberapa aspek yang diukur, yaitu membuat kesimpulan hasil pengukuran diinterpretasikan melalui grafik dan membuat grafik dengan berbantukan program excel. Terkait indikator ini, mahasiswa menunjukkan mahasiswa kompetensi mereka yang sudah berada pada kategori sangat mampu. Hal ini dapat dilakukan oleh mahasiswa karena mereka sudah mahir mengoperasikan computer, khususnya menjalankan program excel sehingga membuat grafik mudah bagi mereka.

\section{b. Faktor-faktor yang Mempengaruhi Tingkat Kemampuan Mahasiswa dalam Mengoperasikan Alat-alat Laboratorium \\ 1. Pengetahuan terhadap alat-alat laboratorium}

Pengetahuan terhadap alat-alat laboratorium merupakan faktor yang paling utama yang mempengaruhi kemampuan mahasiswa dalam mengoperasikan alat laboratorium. Kemampuan yang harus dikuasai oleh mahasiswa yaitu: a) mengetahui nama serta fungsi alat dan bahan yang sesuai rencana praktikum; b) mampu mengkalibrasi alat serta memelihara peralatan laboratorium secara intens dan berkelanjutan; c) mengoperasikan dan menggunakan alat laboratorium sesuai fungsinya masing-masing; d) mampu membaca, mencatat serta menganalisis data; dan, d) mampu bekerja aman sesuai dengan prosedur keselamatan kerja (Said, 2011).

Untuk mengetahui berapa besar pengaruh pengetahuan awal terhadap kemampuan mahasiswa dalam mengoperasikan alat laboratorium penulis menggunakan uji regresi linear dimaksudkan untuk mengetahui pengaruh antara masing-masing variabel bebas (independent variabel) yang dalam hal ini adalah pengaruh pengetahuan awal terhadap kemampuan mahasiswa dalam mengoperasikan alat laboratorium. Hasil pengujiannya adalah sebagai berikut:

Tabel 1.

Uji regresi pengaruh pengetahuan alat-alat laboratorium terhadap kemampuan mahasiswa dalam mengoperasikan alat laboratorium

$\begin{array}{cccc}\begin{array}{c}\text { Unstandardized } \\ \text { Coefficients }\end{array} & \begin{array}{c}\text { Standardized } \\ \text { Coefficients }\end{array} & \mathrm{t} & \text { Sig. }\end{array}$

B Std. Error Beta

\begin{tabular}{|c|c|c|c|c|c|c|}
\hline \multirow{2}{*}{1} & (Constant) & 25.680 & 11.531 & & 2.227 & .036 \\
\hline & $\begin{array}{l}\text { Pengetahuan_A } \\
\text { wal }\end{array}$ & .704 & .218 & .559 & 3.236 & .004 \\
\hline
\end{tabular}


Berdasarkan hasil perhitungan tabel diatas berbantukan aplikasi SPSS windows 2.0 diperoleh bahwa nilai signifikansinya sebesar 0,004 lebih kecil dari nilai taraf signifikansi sebesar 0,05. Hal ini menunjukan bahwa terdapat pengaruh pengetahuan alat-alat laboratorium terhadap kemampuan mahasiswa dalam mengoperasikan alat laboratorium mahasiswa Program Studi Tadris Fisika IAIN Kendari.

Berdasarkan hasil wawancara dengan saudari Rini Putpita Sari terkait dengan pengetahuan terhadap alat-alat laboratorium menyatakan bahwa: "Tentu ada. Factor yang dimaksud adalah factor pengetahuan. Praktikan tidak akan bisa menyiapkan alat yang akan digunakan dalam percobaan jika praktikan belum mengetahui atau diberi arah mengenai nama, jenis, kegunaan, bahaya dan lain sebagainya dari alat tersebut. Oleh karena itu biasanya sebelum praktikum asisten memberikan Tugas Pendahuluan dan biasa berisi nama, kegunaan serta bahaya alat dan bahan yang akan digunakan".

Hasil ini sejalan dengan penelitian yang dilakukan Khusucidah Laila menyatakan bahwa ada korelasi positif antara pengetahuan peserta didik tentang alat praktikum dan kemampuan psikomotorik siswa kelas XI IPA SMAN 11 Semarang dengan tingkat korelasi sebesar 0,60 dan konstribusi tentang pengetahuan peralatan praktikum terhadap kemampuan psikomotorik peserta didik sebesar 36\% (Laila: 2006)

satu faktor yang penting untuk mendukung kegiatan praktikum. Siswa akan terampil dalam praktikum apabila mereka mempunyai pengetahuan mengenai alat-alat praktikum yang meliputi nama alat, fungsi alat dan cara menggunakannya. Pengetahuan alat yang kurang akan mempengaruhi kelancaran saat praktikum, selama praktikum siswa dilibatkan aktif dengan pemakaian alat dan bahan. Mahasiswa yang menguasai alat dengan baik akan lebih terampil dan teliti dalam praktikum sehingga mahasiswa memperoleh hasil praktikum seperti yang diharapkan. Oleh karena pelaksanaan praktikum melibatkan alat-alat, maka perlu penguasaaan tentang alat-alat praktikum dengan baik sehingga dapat menunjang kelancaran praktikum dan memberi nilai tambah bagi penilaian psikomotorik siswa.

\section{Ketersedian Alat-alat Laboratorium}

Selain faktor pengetahuan yang sangat mempengaruhi dalam penelitian ini, faktor ketersediaan alat-alat juga mempengaruhi kemampuan mahasiswa dalam mengoperasikan alat-alat laboratorium. Ada beberapa mahasiswa yang mengungkapkan bahwa salah satu faktor yang mempengaruhi kemampuan menggunakan alat laboratorium yaitu ketersediannya alat dan bahan di laboratorium.

Untuk mengetahui berapa besar pengaruh kondisi dan keterbatasan alat dan bahan laboratorium terhadap kemampuan mahasiswa dalam mengoperasikan alat laboratorium penulis menggunakan uji regresi linear 
dimaksudkan untuk mengetahui pengaruh antara masing-masing variabel bebas (independent variabel) yang dalam hal ini adalah kondisi dan keterbatasan alat dan bahan laboratorium terhadap kemampuan mahasiswa dalam mengoperasikan alat laboratorium. Hasil pengujiannya adalah sebagai berikut:

Tabel 2.

Uji regresi Kondisi dan Ketersedian alat-alat laboratorium terhadap kemampuan mahasiswa dalam mengoperasikan alat laboratorium

\begin{tabular}{|c|c|c|c|c|c|}
\hline \multirow[t]{2}{*}{ Model } & \multicolumn{2}{|c|}{$\begin{array}{l}\text { Unstandardized } \\
\text { Coefficients }\end{array}$} & \multirow{2}{*}{$\begin{array}{c}\text { Standardized } \\
\text { Coefficients } \\
\text { Beta }\end{array}$} & \multirow[t]{2}{*}{$\mathrm{t}$} & \multirow[t]{2}{*}{ Sig. } \\
\hline & B & $\begin{array}{c}\text { Std. } \\
\text { Error }\end{array}$ & & & \\
\hline (Constant) & 41.583 & 10.181 & & 4.085 & .000 \\
\hline Kondis & .552 & .263 & .402 & 2.103 & .047 \\
\hline
\end{tabular}

Berdasarkan hasil perhitungan tabel diatas berbantukan aplikasi SPSS windows 2.0 diperoleh bahwa nilai signifikansinya sebesar 0,047 lebih kecil dari nilai taraf signifikansi sebesar 0,05. Hal ini menunjukan bahwa kondisi dan keterbatasan alat dan bahan laboratorium berpengaruh secara signifikan terhadap kemampuan mahasiswa dalam mengoperasikan alat laboratorium mahasiswa Program Studi Tadris Fisika IAIN Kendari.

Berdasarkan hasil wawancara oleh saudari Rini Putpita Sari tentang ketersedian alat dan bahan pada saat praktikum manyatakan bahwa "jika alat dan bahan tidak memadai maka kita tidak dapat melakukan kegiatan praktikum. Adapaun mungkin tetap dilaksanakan tetapi tidak maksimal dikarenakan kendala alat dan bahan. Alat dan bahan memiliki peran terpenting dalam pelaksanaan praktikum atau percobaan. Pada praktikum fisika dasar yang telah dilakukan sebelumnya menurut saya masih kurang maksimal dikarenakan ada beberapa alat yang digunakan secara bergantian dalam satu waktu praktikum dengan percobaan yang berbeda. Disamping itu, banyaknya alat yang kondisinya tidak memadai sehingga saya sebagai praktikan memberikan jawaban tidak sesuai dengan hasil pengukuran sebenarnya". Disamping itu, saudari Yuli La Isa saat diwawancarai mengutaran bahwa Sarana dan prasarana sangat mendukung dalam proses praktikum terutama alat dan bahan serta hal yang mempengaruhi dalam persiapan alat dan bahan yang digunakan dalam percobaan adalah kurangnya alat dan bahan yang tersedia, adapun alat yang tersedia sudah rusak yang diakibatkan alat tersebut sudah lama. 


\section{KESIMPULAN}

Hasil penelitian atas analisis kemampuan mahasiswa Tadris Fisika IAIN Kendari dalam mengoperasikan peralatan laboratorium sebagaimana yang telah diuraikan sebelumnya, dapat ditarik beberapa kesimpulan. Pertama, secara umum kemampuan mahasiswa mampu mengoperasikan peralatan laboratorium. Akan tetapi, masih ada beberapa indikator kemampuan yang belum dikuasai oleh mahasisiwa, terutama pada dalam mengoperasikan alat ukur Ammeter dan Voltmeter dengan tepat, memasang alat ukur secara tepat berdasarkan rangkaian, membaca hasil pengukuran pada alat ukur, dan menginterpretasikan hasil pengamatan berisi data sesuai dengan percobaan. Salah satu faktor yang mempengaruhi kemampuan mahasiswa dalam mengoperasikan peralatan laboratorium adalah pengetahuan awal tentang peralatan laboratorium. Hasil penelitian ini menunjukkan bahwa pengetahuan awal mahasiswa berpengaruh secara signifikan terhadap kemampuan dalam mengoperasikan peralatan laboratorium. Selain itu, kondisi dan keterbatasan alat dan bahan laboratorium berpengaruh secara signifikan terhadap kemampuan mahasiswa dalam mengoperasikan alat laboratorium.

\section{DAFTAR PUSTAKA}

Awitaningsih. (2012). Studi pemanfaatan peralatan laboratorium Fisika dalam mendukung pelaksanaan pembelajaran Fisika kelas X dan XI di SMAN Kabupaten Banyuwangi wilayah Selatan-Barat. Jurnal Pembelajaran Fisika, 1(2): 185-191.

Creswell, J. W. (2010). Research design: Pendekatan kualitatif, kuantitatif, dan mixed).Yogyakarta: Pustaka Pelajar.

Decaprio, R. (2013). Tips mengelola laboratorium sekolah. Yogyakarta: Diva Press.

Laila, Khusucidah. (2006) Korelasi Antara Pengetahuan Alat Praktikum dengan Kemampuan Psikomotorik Siswa Kelas XI IPA SMAN 11 Semerang Materi Pokok Laju Reaksi Tahun Pelajaran 2005. Semarang : UNNES Semarang.

Dyasayu. (2011). Evaluasi Pelaksanaan Kegiatan Praktikum IPA Sekolah Menengah Pertama Kabupaten Temanggung, Jurnal. Temanggung: IKIP. 
Emha, H. (2002). Pedoman Penggunaan Laboratorium Sekolah. Bandung: PT Remaja Roesda Karya

Myers, B. E. \& Dyer, J. E. (2005). Effect of investigative laboratory instruction on context knowlegde and science process skill achievement across learning styles. Journal of Agricultural Education, 47.

NSTA. (2008). Standards for Science teacher preparation. NSTA in Collaboration with The Association for The Education of Teachers in Science.

Safriana, S. (2017). Pengaruh kemampuan penggunaan alat ukur listrik terhadap kemampuan psikomotrik mahasiswa pada praktikum elektronika dasar. Jurnal Dedikasi Pendidikan, 1(2), 124-130.

Said, M. L. (2011). Pengantar laboratorium Fisika. Makassar: Alauddin University Press.

Sopiatin, P. (2010). Manajemen belajar berbasis kepuasan siswa. Bogor: Ghalia Indonesia.

Sugiyono. (2013). Metode Penelitian Pendidikan: Pendekatan Kuantitatif, Kualitatif, dan $R \& D$. Bandung: Alfabeta

Sundari, R. (2008). Evaluasi pemanfaatan laboratorium dalam pembelajaran biologi di madrasah aliyah negeri sekabupaten Sleman. Jurnal Penelitian dan Evaluasi Pendidikan, 12(2), 196-212. 